\title{
TUBERKULOMA SEREBRAL PADA PENDERITA ACQUIRED IMMUNE DEFICIENCY SYNDROME
}

\author{
CEREBRAL TUBERCULOMA IN ACQUIRED IMMUNE DEFICIENCY SYNDROME \\ PATIENT
}

Dony Ardianto, ${ }^{*}$ Gama Sita Setya Pratiwi, ${ }^{*}$ Vincent Ongko Wijaya, ${ }^{*, * *}$ Anton Mahendra, ${ }^{* * * *}$ Glennis Widra Shintyalola, ${ }^{* * * * *}$ Rasi Irfan Asany ${ }^{* * * * *}$

\begin{abstract}
Cerebral tuberculoma is a central nervous system complication which rare and jeopardize due to tuberculosis (TB) infection. The authors reports a case of a 23 years old female with history of human immunodeficiency virus infection and acquired immunodeficiency syndrome (HIV/AIDS) and under treatment for active TB, presented with headache and dizziness since 1 week before admission. Neurological examination in normal range. Lab value showed decrease level in CD4 absolute and continue with contrast head CT scan. The patient has been given main therapy with dexamethasone, cotrimoxazole, and anti-tuberculosis drugs.
\end{abstract}

Keywords: HIV/AIDS, tuberculoma, tuberculosis

\begin{abstract}
ABSTRAK
Tuberkuloma serebral merupakan komplikasi sistem saraf pusat yang jarang dan berbahaya akibat infeksi tuberkulosis (TB). Kondisi imunosupresif pada infeksi human immunodeficiency virus infection and acquired immunodeficiency syndrome (HIV/AIDS) merupakan faktor resiko dari perkembangan penyakit. Dilaporkan kasus seorang perempuan berusia 23 tahun dengan riwayat HIV/AIDS dan dalam pengobatan TB aktif dengan keluhan nyeri kepala dan pusing berputar sejak 1 minggu sebelum masuk rumah sakit. Pemeriksaan neurologis dalam batas normal. Pemeriksaan penunjang laboratorium menunjukkan penurunan kadar CD4 absolut dan dilanjutkan CT scan kepala dengan kontras. Pasien mendapat terapi utama deksametason, kotrimoksazol, dan obat anti tuberkulosis.
\end{abstract}

Kata kunci: HIV/AIDS, tuberkuloma, tuberkulosis

${ }^{*}$ Departemen Neurologi, RSUD Salatiga, Jawa Tengah; ${ }^{* *}$ FK Universitas Kristen Duta Wacana, Yogyakarta; ${ }^{* * *}$ FK Universitas Muhammadiyah Purwokerto, Jawa Tengah. Korespondensi: vincent_wijaya007@yahoo.com.

\section{PENDAHULUAN}

Tuberkulosis (TB) merupakan penyakit infeksi yang telah dikenal sejak seabad yang lalu, pertama kali diidentifikasi oleh Robert Koch dan hingga kini tetap menjadi masalah bagi kesehatan manusia. Pada tahun 2017, World Health Organization merilis data dimana terdapat lebih dari 10 juta kasus TB diseluruh dunia, dan 1,7 juta penderita diantara nya menimbulkan kematian. Sekitar $1 \%$ dari kasus TB akan bermanifestasi menjadi TB sistem saraf pusat (SSP). ${ }^{1,2}$

Tuberkuloma otak merupakan bentuk serius dan langka dari infeksi TB SSP disamping meningitis atau abses otak TB yang disebabkan oleh penyebaran secara hematogen oleh Mycobacterium tuberculosis (MT). Sistem imun berperan penting dalam perkembangan infeksi TB ekstraparu, beberapa faktor predisposisi yang berperan meliputi usia muda terutama anak-anak dan pada keadaan imunosupresif seperti pada AIDS atau kanker. ${ }^{2}$

\section{KASUS}

Seorang perempuan berusia 23 tahun datang ke instalasi gawat darurat mengeluhkan nyeri kepala yang tidak terlalu berat dan pusing berputar yang dirasakan setiap hari dan cukup berat sejak 1 minggu sebelum masuk rumah sakit. Sebelumnya, pasien sudah lama mengeluhkan keluhan nyeri kepala dan pusing yang muncul hilang timbul sejak 1,5 bulan yang lalu, namun lama kelamaan keluhan semakin frekuen hingga minimal 1x dalam sehari dan keluhan makin memberat. Gejala mual dan muntah disangkal. Keluhan lain yang dirasakan adalah berat badan pasien turun $2 \mathrm{~kg}$ dalam 1 bulan terakhir. Skor visual analog scale (VAS) adalah 3 untuk nyeri kepala ringan.

Pasien sebelumnya terdiagnosis TB paru dan HIV/AIDS positif disaat bersamaan 2 bulan yang lalu dan sedang dalam pengobatan obat anti tuberkulosis (OAT) bulan kedua. Tidak ditemukan adanya riwayat keluhan pusing serupa atau riwayat penyakit 
keluarga sebelumnya. Pasien sudah menikah selama 2 tahun dan belum mempunyai anak. Pasien tidak mengetahui tentang riwayat kontak dengan penderita TB maupun HIV sebelumnya.

Pada pemeriksaan fisik menunjukkan pasien dalam keadaan sadar penuh dan tampak kurus, kekuatan motorik sisi kiri dan kanan 5, reflek fisiologis normal, tidak didapatkan adanya reflek patologis. Pemeriksaan saraf kranialis, tanda rangsang meningeal, dan pemeriksaan serebelum (tremor, tes romberg, nystagmus, disdiadokokinesia, dan tes finger to nose menunjukkan hasil negatif) dalam batas normal. Pasien termasuk underweight atau kategori malnutrisi ringan dengan indeks massa tubuh sebesar $17 \mathrm{~kg} / \mathrm{m}^{2}$ dan berat badan $40 \mathrm{~kg}$.

Pemeriksaan darah lengkap lengkap, ureum, dan kreatinin menunjukkan hasil normal. Hasil pemeriksaan lainnya menunjukkan penurunan kadar CD4 absolut $(35 \mathrm{sel} / \mu \mathrm{l})$. Sebaliknya, terdapat peningkatan kadar SGOT (155 U/l) dan SGOT (84 U/l)

Pada CT scan kepala terdapat terdapat edema fokal multipel di regio frontal kiri, temporal kiri, dan oksipital kanan. Pasca kontras tampak ring enhancement dengan central solid hipodens, ukuran bervariasi $8-14 \mathrm{~mm}$. Kesan radiologis menunjukkan lesi tuberkuloma dengan edema fokal multipel di regio frontal, temporal kiri dan oksipital kanan disertai infark putamen kiri, nukleus kaudatus kiri, krus anterior kapsula interna kiri, dan thalamus kanan (Gambar 1).

Pasien mendapatkan terapi injeksi ketorolak $30 \mathrm{mg} / 8$ jam untuk nyeri kepala, injeksi omeprazol $40 \mathrm{mg} / 12$ jam, injeksi vitamin neurotropik (B1, B6, B12) $3 \mathrm{ml} / 24 \mathrm{jam}$, injeksi sitikolin $250 \mathrm{mg} / 12 \mathrm{jam}$, injeksi deksametason $5 \mathrm{mg} / 6$ jam, kotrimoksazol oral $480 \mathrm{mg} / 12$ jam untuk profilaksis infeksi HIV oportunistik, dan melanjutkan terapi obat isoniazid $(\mathrm{H})$, rifampisin $(\mathrm{R})$, pirazinamid $(\mathrm{Z})$, dan etambutol (E) sesuai pengobatan TB kategori 1 dengan 3 tablet 4 fixed drug combination (FDC) selama fase intensif. Kondisi pasien membaik dengan gejala minimal setelah 1 minggu rawat inap dan dilanjutkan rawat jalan.

\section{PEMBAHASAN}

Tuberkuloma telah diartikan sebagai lesi massa pada jaringan otak yang terbentuk dari jaringan granulasi yang tersusun dari campuran tuberkel dan sel radang lainnya. Lesi ini dapat single atau multiple, dan dapat muncul di lokasi otak manapun, serta ukuran yang bervariasi dari beberapa milimeter hingga 3-4 cm. Penyakit sistem saraf pusat yang diakibatkan MT mempunyai memiliki efek yang sangat berbahaya, walaupun angka prevalensinya sangat kecil hingga 1\%. Data epidemiologi oleh Centers of Disease Control and Prevention (CDC) mengindikasikan pada $6,3 \%$ kasus TB ekstra pulmo (1,3\% dari total kasus TB) memiliki infeksi TB sistem saraf pusat (SSP). Infeksi TB SSP dibagi menjadi intrakranial dan spinal tergantung lokasinya. TB intrakranial meliputi meningitis TB, ensefalopati TB, vaskulopati TB, abses otak TB, dan tuberkuloma. TB spinal meliputi penyakit Pott, tuberkuloma spinal, dan meningitis spinal. ${ }^{4}$

Angka mortalitas yang tinggi umumnya mempengaruhi kelompok usia anak-anak dan individu dengan infeksi HIV. Pasien pada kasus ini memiliki riwayat HIV/AIDS sebagai komorbid utama. Hingga kini belum ada studi epidemiologi spesifik selain laporan kasus yang menunjukkan angka kejadian tuberkuloma pada pasien HIV/AIDS, menunjukkan kejadian kasus yang cukup langka. Faktor resiko yang berperan selain usia anak-anak dan koinfeksi HIV adalah malnutrisi, malignansi, dan penggunaan alkohol, rokok tembakau, dan agen imunosupresif. ${ }^{3-5}$

Perkembangan penyakit ini berasal dari kompleks primer yang berisi bakteri basil MT yang menyebar secara hematogen dan menginfiltrasi meninges saat infeksi primer. Fokus ini tidak selalu ruptur di lapisan dura otak, namun secara lokal menyebar dan membentuk granuloma di di antara parenkim otak. Jaringan otak disekitar lesi terkompresi dan meunjukkan edema dan perubahan gliotik. ${ }^{6,7}$

Tuberkuloma umumnya memiliki gejala yang tidak spesifik. Berbeda dengan menigitis TB yang memiliki gejala klinis yang berat. Gejala yang timbul umumnya akibat proses desak ruang lesi dan peningkatan tekanan intrakranial. Manifestasi neurologis yang timbul dipengaruhi oleh ukuran, lokasi, dan jumlah lesi. Pada dewasa, 
lokasi tuberkuloma lebih sering muncul di area supratentorial, sedangkan pada anak cenderung di daerah infratentorial. ${ }^{8-9}$

Gejala tuberkuloma umumnya bervariasi, seperti nyeri kepala, kejang, paresis saraf kranialis, atau tanda klinis lainnya yang berhubungan dengan peningkatan tekanan intrakranial. Manifestasi klinis yang non spesifik ini hampir tidak bisa dibedakan dengan lesi space occupying lainnya, sehingga sangat esensial untuk mengevaluasi etiologi lain seperti malignansi, sarkoidosis, abses piogenik, atau toksoplasmosis. ${ }^{10-11}$

Penegakan diagnosis tuberkuloma intrakranial dapat menjadi tantangan tersendiri dan umumnya ditegakkan melalui kombinasi anamnesis, studi imaging, dan hasil laboratorium. Pemeriksaan radiologis sendiri tidak cukup diakibatkan kurangnya gambaran spesifik terhadap lesi, karena gambaran yangmirip antara etiologi infeksi dan non-infeksi.Pada gambaran CT scan, tuberkuloma di karakteristikkan sebagai massa hipo atau hiperdens dengan batas bulat atau lobular. Lesi dapat menunjukkan ring enhancement pada penggunaan kontras, seperti yang tampak pada gambaran radiologis pasien di kasus ini, namun perlu diperhatikan bahwa gambaran ini juga dapat muncul pada penyakit lain. Pasca terdiagnosa, respon terapi dapat terlihat dan dinilai melalui gambaran radiologis setelah 4 hingga 6 minggu. ${ }^{6,11}$

Gambaran pencitraan pada kasus ini juga tampak adanya infark ditandai dengan gambaran lesi hipodens $18 \mathrm{HU}$ di area putamen kiri, nukleus kaudatus kiri, krus anterior kapsula interna sinistra, dan thalamus kanan. Infark iskemik juga merupakan salah satu komplikasi yang sering ditemukan, pada 20-41\% pasien yang terdeteksi melalui hasil CT scan, yang seringkali berada di area ganglia basal atau kapsula interna akibat kompresi vaskular dan oklusi pada pembuluh darah perforata (necrotizing arteritis). ${ }^{2}$

Analisa cairan serebrospinal tidak terlalu membantu, walaupun dapat terjadi peningkatan ringan kadar protein. Dalam beberapa kasus khusus dimana tidak terdapat bukti infeksi TB aktif di lokasi manapun di tubuh, biopsi otak dapat menjadi pilihan. Namun, prosedur invasif umumnya tidak pernah digunakan karena resikonya yang tinggi. Tindakan ventriculoperitoneal (VP) shunt dapat dilakukan apabila terdapat indikasi seperti hidrosefalus, massa yang menyebabkan blokade jalur CSF, perburukan gejala klinis atau defisit neurologis akibat peningkatan tekanan intrakranial dari efek massa. ${ }^{12,13}$

Terapi awal TB intrakranial dengan medikamentosa yang digunakan pada kasus ini adalah pengobatan TB ekstra paru dengan obat anti

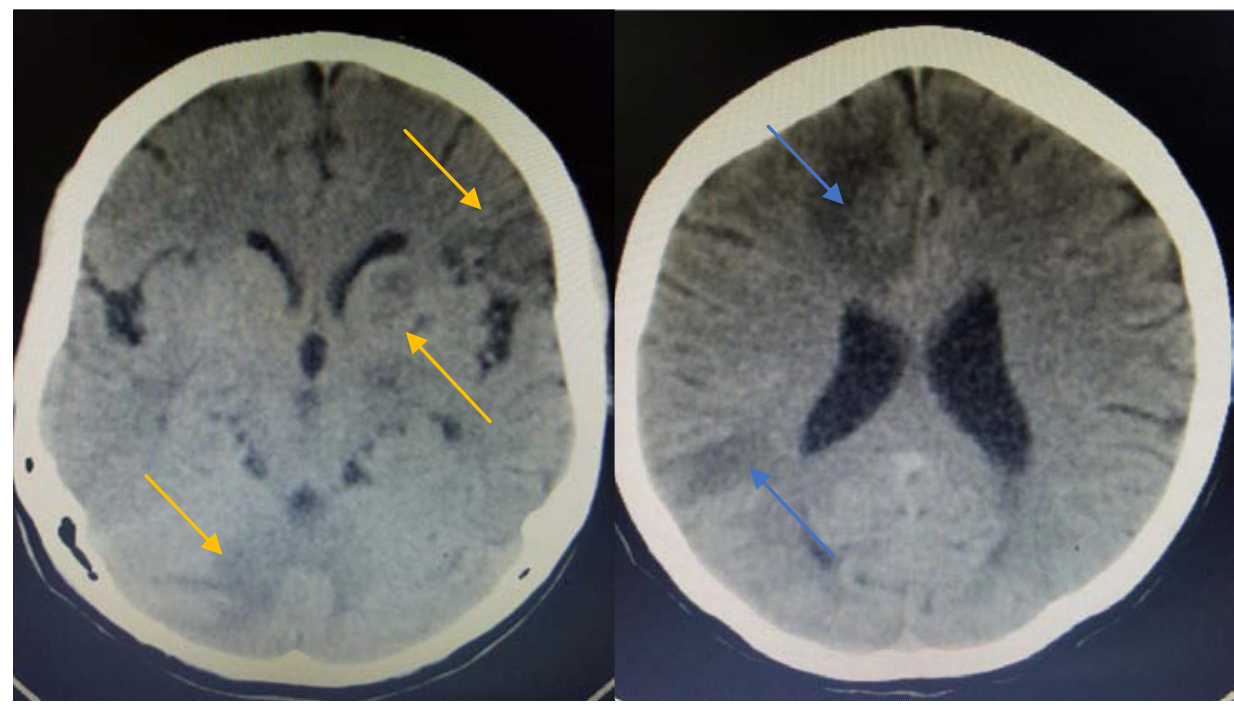

(a)

(b)

Gambar 1. Potongan Aksial CT Scan dengan Kontras

(a) Tampak tuberkuloma dengan infark multipel disertai edema fokal (panah kuning) (b) tampak lesihipodens dengan ring enhancement dan edema perifokal (panah biru). 
tuberkulosis kategori 1 meliputi 4 FDC (fixed drug combination) dengan RHZE (isoniazid, rifampisin, pirazinamid, dan etambutol) selama 2 bulan awal untuk fase intensif dan diikuti oleh 7 sampai 10 bulan tambahan isoniazid $(\mathrm{H})$ dan rifampisin $(\mathrm{R})$ sebagai terapi pemeliharaan. Panduan menurut peraturan menteri kesehatan menganjurkan, pada pasien HIV/ AIDS dengan TB ekstra paru, panduan OAT diberikan paling sedikit 9 bulan (2 bulan RHZE diikuti dengan 7 bulan RH). Sedangkan, TB ekstra paru pada sistem saraf pusat (tuberkuloma atau meningitis) dan TB tulang/sendi, direkomendasikan setidaknya selama $10-12$ bulan. ${ }^{14-15}$

Terapi lain yang diberikan adalah pemberian kotrimoksazol $480 \mathrm{mg}$ diberikan 2 tablet per hari. Dalam pedoman klinis juga menganjurkan pada pasien TB dengan infeksi HIV perlu diberikan profilaksis kotrimoksazol sebagai pencegahan infeksi oportunistik terutama pada pasien dengan nilai CD4 $<200$ sel $/ \mathrm{mm}^{3}$ selama 2 minggu sebelum memulai terapi ARV. Kotrimoksazol merupakan antibiotik spektrum luas yang mencakup bakteri aerobik gram positif dan negatif, beberapa penelitian telah menunjukkan penurunan angka infeksi oportunistik akibat cotrimoxazole prophylactic therapy (CPT). Dosis rekomendasi untuk dewasa adalah tablet $480 \mathrm{mg}$ diberikan 2 kali dalam sehari. Terapi dihentikan bila pasien dengan riwayat Stevens-Johnson syndrome (SJS), penyakit hati berat, anemia atau pansitopenia berat, atau HIV negatif. Kontraindikasi kotrimoksazol meliputi alergi terhadap sulfa, penyakit liver berat, penyakit ginjal berat, dan defisiensi G6PD ${ }^{16-19}$

Pasien juga mendapatkan deksametason $5 \mathrm{mg}$ setiap 6 jam. Terapi ajuvan kortikosteroid sebaiknya ditambahkan pada TB intrakranial. Deksametason dapat mengurangi respon awal inflamasi intraserebral, mencegah infark, pembentukan tuberkuloma, dan mengurangi insidensi immune reconstitution inflammatory syndrome (IRIS). Sindrom pulih imun atau IRIS merupakan spektrum dari perburukan gejala klinis pada ODHA akibat respons inflamasi berlebihan pada saat pemulihan respon imun setelah inisiasi terapi ARV. Kriteria diagnosis sindrom pulih imun meliputi (1) Menunjukkan respons terhadap terapi ARV dengan mendapat terapi ARV dan penurunan viral load $>1$ log kopi/mL; (2) perburukan gejala klinis atau timbul reaksi inflamasi setelah inisiasi terapi ARV; (3) Gejala klinis tersebut bukan disebabkan oleh gejala klinis dari infeksi yang diketahui sebelumnya yang telah berhasil disembuhkan, efek samping obat atau toksisitas, kegagalan terapi, atau ketidakpatuhan menggunakan ARV. Sehingga diperlukan pemantauan ketat terapi ARV dalam 6 bulan awal. ${ }^{19-20}$

Deksametason juga dapat mengurangi resiko drug-induced liver injury (DILI) akibat efek samping OAT, sehingga membantu luaran klinis yang baik. Terapi kortikosteroid dimulai secara IV secepatnya, lalu diubah ke bentuk oral tergantung perbaikan klinis. Rekomendasi kortikosteroid yang digunakan adalah deksametason $0,3-0,4 \mathrm{mg} / \mathrm{kg}$ di tapering-off selama 6-8 minggu atau prednison $1 \mathrm{mg} / \mathrm{kg}$ selama 3 minggu, lalu tapering-off selama 3-5 minggu. ${ }^{21}$

Prinsip pengobatan pasien TB dengan HIV/ AIDS adalah mendahulukan pemberian pengobatan TB, dan pengobatan ARV dimulai sesegera mungkin dalam waktu $2-8$ minggu setelah kondisi klinis baik tanpa efek samping dari OAT. Menurut WHO, inisiasi obat ARV pada pasien HIV/AIDS dengan TB sistem saraf pusat diberikan dalam 2-4 minggu setelah pengobatan OAT apabila jumlah CD4 kurang dari $200 \mathrm{sel} / \mathrm{mm}^{3} .^{19,22}$

Prognosis pasien ini baik dengan defisit neurologis ringan. Dibandingkan TB intrakranial lainnya seperti abses atau meningitis, tuberkuloma umumnya memiliki respon yang baik terhadap terapi medikamentosa dan memiliki prognosis yang baik. Tuberkuloma memiliki tingkat mortalitas yang rendah hingga $<10 \%$ dengan terapi OAT yang sesuai. Pada studi kasus, menunjukkan tingkat mortalitas pada pasien tuberkuloma dengan atau tanpa HIV/AIDS memiliki rerata yang sama pada kedua kelompok. Sebaliknya mortalitas yang buruk berhubungan dengan gejala klinis yang buruk, TB meningitis, kadar CD4 $<50 \mathrm{sel} / \mathrm{mm}^{3}$, atau adanya keterlibatan TB kebal obat. ${ }^{23}$

\section{KESIMPULAN}

Tuberkuloma serebral merupakan suatu kondisi ditandai dengan adanya tuberkuloma di 
intrakranial. Gejala klinis umumnya non-spesifik, manifestasi klinis muncul akibat proses desak ruang lesi peningkatan tekanan intrakranial seperti nyeri kepala atau kejang. Pasien dengan kondisi imunokompeten seperti HIV/AIDS memiliki resiko lebih tinggi terkena TB sistem saraf pusat dan tuberkuloma harus selalu dipertimbangkan sebagai diagnosis banding pada lesi ekspansif sistem saraf pusat pada pasien dengan HIV/AIDS. Evaluasi menyeluruh dapat membantu diagnosa, termasuk klinis (anamnesis, pemeriksaan fisik), laboratorium, dan imejing (CT scan). Terapi medikamentosa yang diberikan meliputi terapi definitif dengan OAT, diikuti pemberian profilaksis kotrimoksazol dan adjuvan kortikosteroid.

Dalam 1 minggu pengobatan gejala pasien membaik dan minimal. Pasien diperbolehkan pulang serta direncanakan follow-up rutin dan observasi pemberian obat demi memberikan luaran klinis yang lebih baik bagi pasien.

\section{DAFTAR PUSTAKA}

1. World Health Organization. Global Tuberculosis Report 2017. 2017 Geneva: WHO press.

2. Monteiro R, Carneiro JC, Costa C, Duarte R. Cerebral tuberculomas-a clinical challenge. Respir Med Case Rep. 2013;9:34-7.

3. Henry M, Holzman RS. Tuberculosis of the brain, meninges and spinal cord. Dalam: Rom WN, Garay SM, editor. Tuberculosis. Philadelphia: Lippincot Williams and Wilkins; 2004. h. 445-64

4. Cherian A, Thomas SV. Central nervous system tuberculosis. Afr Health Sci. 2011;11(1):116-27.

5. Giancola ML, Baldini F, Carapella CM, Rizzi EB, Maddaluno R, Alba L dkk. Brain tuberculosisassociated immune reconstitution inflammatory syndrome in an HIV-positive patient: A biopsyproven case. J Infect Dev Ctries. 2015;9(5):536-40.

6. Sethi P, Treece J, Onweni C, Pai V, Rahman Z, Singh S. The importance of a complete differential: case report of a tuberculoma in a patient without pulmonary involvement. Cureus. 2017; 9(6):e1405.

7. Mukherjee S, Das R, Begum S. Tuberculoma of the brain-a diagnostic dilemma: magentic resonance spectroscopy a new ray of hope. J Assoc Chest Physicians. 2015:3:3-8

8. Garg RK. Diagnosis of intracranial tuberculoma. Ind J Tub. 1996;43:35-9.

9. Azeemuddin M, Alvi A, Sayani R, Khan M, Farooq S, Beg MA, dkk. Neuroimaging findings in tuberculosis: a single-center experience in 559 cases. J Neuroimaging. 2019;29(5):657-68.

10. Venter $F$, Heidari A, Galang $K$, Viehweg $M$. An atypical presentation of tuberculomas in an immunocompetent host. J Investig Med High Impact Case Rep. 2018;2018:6

11. Sanei-Taheri M, Karimi MA, Haghighatkhah H, Pourghorban R, Samadian M, Delavar Kasmaei H. Central nervous system tuberculosis: an imagingfocused review of a reemerging disease. Radiol Res Pract. 2015;2015:202806.

12. Vu K, Adler H, Gibbons E, Pearson J, Betz W. Intracerebral tuberculomas: A rare cause of seizure in an immunocompetent young male. IDCases. 2019;18:e0599.

13. Nigim F, Critchlow JF, Kasper EM. Role of ventriculoperitoneal shunting in patients with neoplasms of the central nervous system: An analysis of 59 cases. Mol Clin Oncol.2015;3(6):1381-6. doi: $10.3892 / \mathrm{mco} .2015 .627$

14. Goyal V, Elavarasi A, Abhishek, Shukla G, Behari M. Practice trends in treating CNS tuberculosis and outcomes at a tertiary care. Ann Indian Acad Neurol. 2019; 22(1): 37-46.

15. Ashok Kumar E, Jijiya Bai P. A clinical study of CNS Tuberculomas. IAIM. 2016; 3(6):101-6.

16. World Health Organization. Guidelines on Postexposure Prophylaxis for HIV and the Use of Co-Trimoxazole Prophylaxis for HIV-Related Infections Among Adults, Adolescents and Children: Recommendations for a Public Health Approach: December 2014 Supplement to the 2013 Consolidated Guidelines on the use of Antiretroviral Drugs for Treating and Preventing HIV Infection. 2014. Geneva: World Health Organization; 2014

17. World Health Organization. Consolidated Guidelines on the Use of Antiretroviral Drugs for Treating and Preventing HIV Infection: Recommendations for a Public Health Approach. Geneva: World Health Organization; 2016.

18. Gebresillassie BM, Gebeyehu MB, Abegaz TM, Erku DA, Mekuria AB, Tadesse YD, dkk. Evaluation of cotrimoxazole use as a preventive therapy among patients living with HIV/AIDS in Gondar University Referral Hospital, northwestern Ethiopia: a retrospective cross-sectional study. HIV AIDS. 2016:8:125.

19. Peraturan Menteri Kesehatan No.87. Pedoman Pengobatan ARV. Kementerian Kesehatan Republik Indonesia; 2014.

20. Murthy AR, Marulappa R, Hegde U, Kappadi D, Ambikathanaya UK, Nair P. Treatment guidelines and prognosis of immune reconstitution inflammatory 
syndrome patients: a review. J Int Oral Health. 2015;7(4):92-5.

21. Donovan J, Phu NH, Mai NTH, Dung LT, Imran D, Burhan E, dkk. Adjunctive dexamethasone for the treatment of HIV-infected adults with tuberculous meningitis (ACT HIV): Study protocol for a randomised controlled trial. Wellcome Open Res. 2018;3:31.
22. World Health Organization. Treatment of tuberculosis guidelines. Edisi Ke-4. Geneva, Switzerland: World Health Organization; 2010.

23. Marais S, Roos I, Mitha A, Patel V, Kalincik T, Bhigjee AI. Presentation and outcome of patients with intracranial tuberculoma in a high HIV prevalence setting. Int J Tuberc and Lung Dis. 2020; 24(2):22432. 